

\section{Toidukultuur Hiiumaa Muuseumis: kogumine, uurimine, vahendamine}

Helgi Põllo

\section{Sissejuhatus}

Eestis ei arutleta just sageli selle üle, millised teemad võiksid ja peaksid domineerima kultuuriajaloo kogumise või näituste ja sündmuste poliitikas. Muuseumides on mõttevahetusi küllap rohkem olnud, kuid neist ei jää enamasti jälge. Kuidas me oma eesti mälu ikkagi säilitame? Või milline peaks olema mällu panustamine väikemuuseumides?

Marek Tamm tõdeb, et tavaarusaamas seondub rahvuslik mälu ennekõike muuseumieksponaatide, muististe ja monumentidega (Tamm 2012: 86). Heiki Pärdi rõhutab samuti, et just muuseumidel on voli ja võim otsustada nii selle üle, mida inimesed ja ühiskond mäletavad, kui ka selle üle, mida nad unustavad (Pärdi 1999: 71). Muuseumid, nagu teada, muutuvad praegu kiiresti ja mitte ainult Eestis. See väljendub mõneti isegi mäluasutuste uuendatud missioonis, kus rõhutatakse, et muuseume on pigem vaja kogukonna identiteedi tugevdamiseks, inspireerimiseks, seoste loomiseks või äratundmiseks (Mensch ja Meijer-van Mensch 2015: 14). Uued sõnastused ei keskendu enam niivõrd muuseumide põhitegevustele, sh kogumisele, vaid pigem sellele, milleks ja kellele kollektsioon vajalikuks osutub. SA Hiiumaa Muuseumid missioonis rõhutatakse Hiiumaa ainulaadse pärandiga tegelemise kõrval soovi olla usaldusväärne partner kohalikus kogukonnas. Mõni aeg varem identiteedi hoidmisele keskendunud mõtet on nüüdseks muudetud, nii et tähtsamaks on muutunud just partnerlus. Visioon rõhutab aga, et SA Hiiumaa Muuseumid on arenev, professionaalne, hooldatud taristuga mäluasutus, mis on tõmbekeskuseks turistidele ja teabekeskuseks kohalikule kogukonnale. Kuidas aga tagada just niisuguse teabe kogumist, mis on kohalikule kogukonnale vajalik või osutub selleks edaspidi? Cedreniuse väitel ei piisa meie tänasest objektiivsusest, sest järeltulijad vajavad nagunii teistsugust infot ja materjali kui see, mida me neile 
pakume. Teaduslikel eesmärkidel kogumine kannab samuti ajastu pitserit, sest igal ajastul on oma taust, nn kultuuriprillid, mis näitavad ajalugu ja aega teatud prisma kaudu (Kannike 1999: 33).

Niiviisi arutledes hüppab mõte justkui iseenesest tuntud teoreetiku Abraham Maslow' (1908-1970) juurde, kes on loonud inimestele omaste vajaduste kategoriseerimise ja väärtustamise süsteemi ning visualiseerinud selle püramiidina. Ehk oleks sellest muuseumidelgi midagi aluseks võtta. Võib-olla peaksid argielu nähtuste säilitamisele keskendunud mäluasutuste kogud peegeldama just nimelt Maslow' mõtteviisiga sarnast lähenemist. Püramiidi tipus seisab seal eneseteostus, kõige alumisel ja laiemal platvormil leiame aga n-ö füsioloogilised vajadused, seega ka söömisvajaduse ja toiduteema üldisemalt.

Toidu säilitamine muuseumis pole enamasti võimalik või vähemalt mõistlik. Kuidas siis toimida? Kas pöörduda viimasel ajal üha sageneva küsimuse juurde „Miks peaksid kõik asjad olema säilitatud, kui nad on täiuslikult dokumenteeritud?" Nii küsis oma muuseumikogude tänapäevaseid strateegiaid käsitlevas artiklis ka Francois Mairesse (2010: 61).

Rahvusliku ja kohaliku toidu teema on Eestis ikka aktuaalne olnud. Toit seostubki inimestele sageli rahvuslikkuse, identiteedi, lapsepõlvemälestustega - nende üsna tavapäraste muuseumides käsitletavate valdkondadega. Kui palju on toit laiemalt ja söömine teemana läbi aegade Hiiumaa Muuseumis fookusesse sattunud? Väikemuuseumides polnud aastaid selgelt sõnastatud ettevaatavaid kogumis- ja uurimisplaane. Elu ise andis jooksvalt ülesanded ja nende lahendamise võimalused. Nii saame õnnestumisi ja puudujääke ühes või teises tegevuses vaid tagantjärele konstateerida.

\section{Kogumistöö}

SA Hiiumaa Muuseumid on omaaegse, 1967. aasta kevadel paari kohaliku kooli koduloolise baasi alusel loodud Hiiumaa rajooni koduloomuuseumi järglane. Seega täitus muuseumi loomisest juba 50 aastat. Kui heita kiire tagasivaatav pilk esimeste aastakümnete kollektsioonile, leiame sealt palju 19. sajandi eluolu iseloomustavaid töö- ning tarberiistu, sealhulgas toidu valmistamise, säilitamise või otse söömisega seotud nõusid ja muid tarvikuid. Nimetada tasub puukausse, toidukarpe ehk rasju, kanne, kappasid, võimasinaid, puulusikaid, katlaahelaid, trehtleid jms.

Esemetega kaasa tulnud napp info räägib toiduteemast ainult riivamisi, küll on aga palju juttu esemete valmistamisest, kaunistamisest ja materjalivalikust. Kui võtta ette üks tavaline puukauss, piirdub selle kirjeldus muuseumis ju enamasti andmetega selle kohta, millest, millal ja kes selle valmistas, mitte selle kohta, mitu korda Mari selles piima hapendas või mitu pereliiget sellest koos sõi. Konkreetset valmistamisinfot oli ja on ka eseme andjal palju lihtsam meeles hoida kui selle kasutamise pikka ja kirevat lugu.

Koduloomuuseumi algaastail jätkus kogu täiendamine enam-vähem samas vaimus, sest 18.-19. sajandi etnograafiline materjal kadus nõukogudeaegsetes oludes võrdlemisi kiirelt, mis iseenesest lõi tunde ohuolukorrast. Samas ei olnud anne- 
tajate hulgas enam palju neid, kes oleksid suutnud kogutavatele esemetele isiklike mälestustega lisaväärtust anda. Olid niisiis lihtsalt huvitavad ajaloolised asjad Hiiumaalt.

Juba muuseumi teisel tegevuskümnendil hakati järjest enam tähelepanu pöörama arhiivi täiendamisele. See kasvas tasapisi ja omasoodu mälestuste või lühiuurimustega endisaegsest elust, mille hulgas sattus olema ka lühemaid lugusid kohalikest toitudest või söömistavadest (nt HKM 2440A30; 6062:3/A314). Justnimelt sattus olema, sest konkreetset küsitluskava muuseumil polnud, samuti ei olnud korrespondentide võrku ega ka kohalike inimeste koostööharjumust muuseumiga. Pigem saadeti oma kirjatööd juba tuttavale ja usaldusväärsele Eesti Rahva Muuseumile.

Muutused poliitilises elus sundisid aga mõtlema, kuidas seda, mis ümberringi toimub, eriti tavapärast ja argielulist, muuseumis paremini jäädvustada. Nii jõuti Hiiumaa Muuseumiski tõdemuseni, et paljud asjad tuleks fikseerida kohe täna ja praegu. Aga kuidas? 1990. aasta esimeste vabade jõulude järel tehti muuseumi initsiatiivil kiirküsitlus mõnes kohalikus koolis ning grupi pensionäride hulgas, eesmärgiks koguda vahetuid mälestusi neist taas kord lubatud pühadest. Üks viiest küsimusest puudutas jõululaual olnud toitu. Nüüd on sellest varsti juba 30 aastat möödas ja isegi need enamasti võrdlemisi napisõnalised vastused muutuvad järjest tähenduslikumaks. (HKM 3955:1-3/A60-62 ja HKM 4523/A219)

Üheks eriti iseloomulikus näiteks neist üleminekuaegadest on meie kogus üks toiduainete väljaveoluba Hiiumaalt aastast 1992. See paar nädalat kehtinud tõend lubas eraisikul viia oma sugulaste juurest mandrile $100 \mathrm{~kg}$ kartulit, 10 karpi liha- ja 10 karpi kalakonserve ning 3 kg soolasilku. (HKM 5764:1/A 4358)

1990. aastatel ja 2000. aastate alguses toimus Hiiumaal mitu omakultuuri kursust nii Hiiumaa ametikoolis (varasem Suuremõisa Tehnikum) kui ka koolituskeskuses Tuuru, kus põhiõpetajateks olid samuti muuseumitöötajad. Muuseumi koostöö Tuuruga kujunes pikaks ja produktiivseks. Muu põneva kõrval korraldati mõned kohalikule toidule pühendatud oppepäevad, mida juhendasid ikka korralikult asja tundvad kokad ja pärimusekandjad, kuid ajaloolise ülevaate andmine Hiiumaa toidutraditsioonist jäi muuseumi õlule. Nii toimus neil kordadel näiteks hiidlastele tuntud käkisupi valmistamine või säinakotlettide tegemine. Muuseumi eestvedamisel on nüüdseks koostatud käkisupi valmistamist tutvustav sissekanne ja kantud see Eesti vaimse pärandi nimistusse. Marek Tamm toonitas Eesti mälu puudutavas artiklis (Tamm 2012: 86), et mäluasutused astuvad suure sammu oma algsele kutsumusele lähemale just siis, kui nad suunavad rohkem tähelepanu mittemateriaalsetele mälupaikadele. Hiiumaa Muuseum on just seda teinudki, olles seotud UNESCO Eesti vaimse pärandi nimistu sissekannete koostamise ja pärandi väärtustamisega nüüd juba üle 10 aasta.

Selliste toidule orienteeritud tegevuste valguses hakkas muuseumist kujunema kohalike elanike jaoks omakultuuri, sh kohalikku toitu tundev mäluasutus, mis omakorda nõudis muuseumitöötajate paremat ettevalmistust sel alal, aga ka jõukohaste uurimis- ning välitööde tegemist. Loomulikult tuli ikka ja jälle korraldada seminare ning pidada loenguid sellestsamast Hiiumaa kohalikust ja traditsioonilisest toidust, toetudes varem kirjapandule või kohapealt juurde kogutud materjalile. Projektide või tudengitele soovitatud uurimisteemade kaudu tegelesid kohaliku 
kultuurilooga ka mitmed õppurid, kelle referaate ja lühiuurimusi võeti valikuliselt arvele põhikogusse või muuseumi käsiraamatukokku. Kuna 21. sajandi algus oli hiidlaste jaoks ka esimese kogu saart puudutava ulatusliku koguteose koostamise aeg, kogusin välitöödega paralleelset hiiu toiduga seotud materjali arhiividest ja teiste muuseumide fondidest (Eesti Rahva Muuseum, Eesti Kirjandusmuuseum jt). Raamat, mis sisaldab ka toiduteemalist artiklit, ilmus 2015. aastal (Põllo, Telvik, Mäeots 2015). Selle koostamisel ilmnes taas üks puudujääk muuseumi kollektsioonis: toidu ja söömisega seotud fotode vähesus või nende sisuline ühetaolisus. Reeglina oli jäädvustatud pidupäevi, argihetki oli väga vähe, eriti mis puudutab mõnda spetsiifilist valdkonda, näiteks kalapea, hülgeliha, kuivatatud lambakintsu jms söömist või söögiks ettevalmistamist. Hiljaaegu selgus, et isegi tavalist süldisöömist on fotodelt raske leida. Nüüd tuleb siis nende ja teiste teemadega eraldi tegeleda. Lisauurimist vajaks kasvõi söömine ja toit laeva- ja teistel pikematel reisidel. Jätkuvast huvist toiduteema vastu olen nüüd jälle tasapisi alustanud tänapäevase materjali talletamist kirjutiste-küsitluste kogumisega teemal „Mida, kus ja kuidas sa eile sõid?" Sellisel moel saab minimeerida ebatäpsust, mis käib kaasas pikalt tagasiulatuvate mälestustega. Järjest rohkem tellivad MTÜ-d, projektiseltskonnad ja ettevõtted, kes pakuvad ja tutvustavad kohalikku toitu, muuseumilt ettekandeid või toiduteemalisi ajalookäsitlusi, näiteks on neile antud kokkuvõtvad ülevaated süldikeetmisest ja kuivatatud lambaliha kodusest valmistamisest saarel.

Uusi esemeid kogudes ei ole söömise ja toidu teema viimasel ajal kuigi oluline olnud. Tõsi, näitusele „Köök“ (2014-2015) laenasime küll kogukonnaliikmetelt

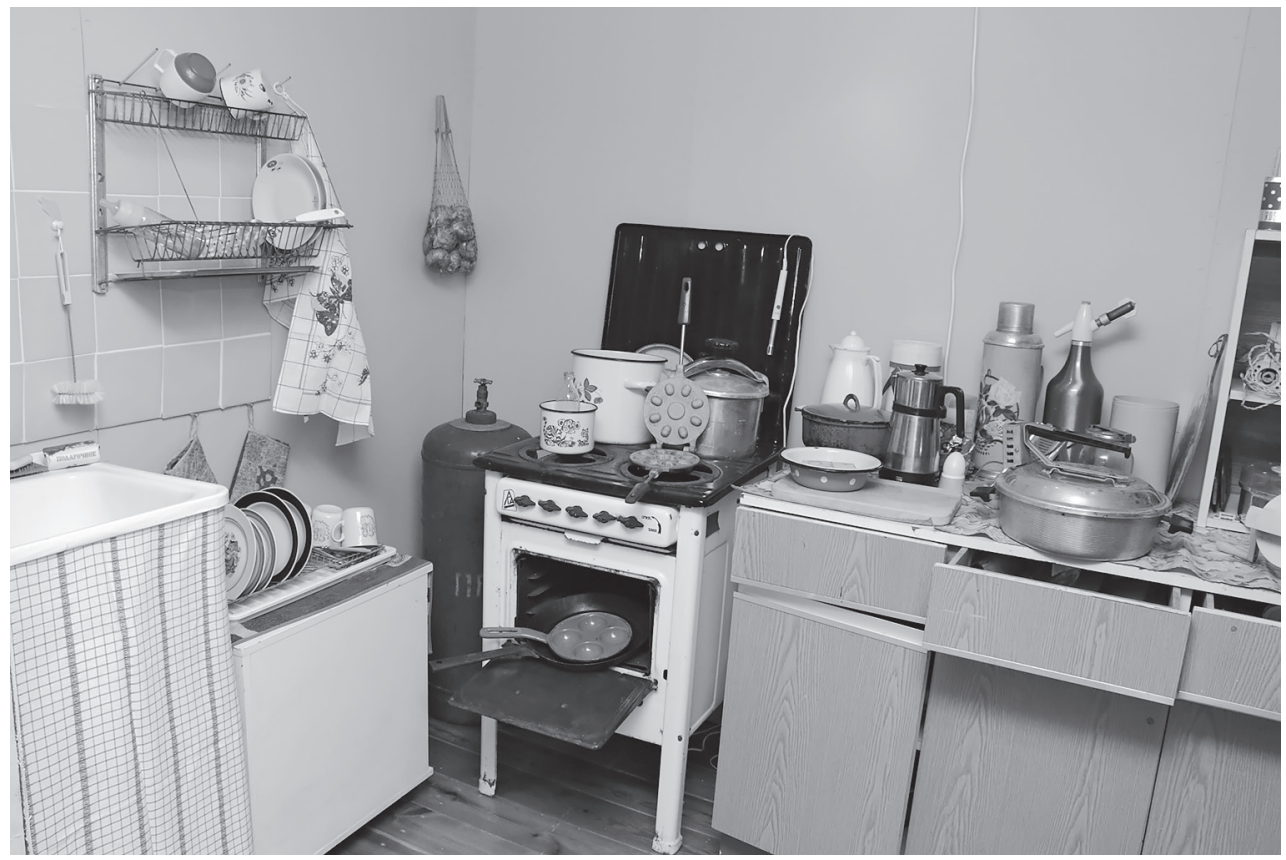

Foto 2. Näitus „Köök“ - 1980. aastad. 
suure hulga esemeid. Mõned neist sai võetud muuseumi abikogusse, sest see, mil määral arvata põhikogusse nõukogudeaegset masstoodangut, polnud ja pole uute kogumisnõuete valguses lõpuni läbi vaieldud. Mõni varem kogutud museaal on seevastu pälvinud üldist ja lausa riiklikku tähelepanu. Näitena võib tuua UngernSternbergidele kuulunud hõbedast kannu, mis 2004. aastal kogusse jõudis (Liivamägi 2004). Mõne eseme puhul hoiame jälle ise kõrgendatud huvi üleval, mille heaks näiteks on Kärdlas malmivaluna valminud ahjupann (HKM 2323:52/AjN 1018). Üks selline on muuseumil juba olemas, aga kohapealset ning üle saja aasta vanust toodangut võiks võrdlusmaterjalina rohkemgi olla. Siin mainitud esemed on korduvalt kasutamist leidnud meie näitustel ja õpilasprogrammides. Ese muuseumis annab, nagu me hästi teame, tõlgendamiseks palju võimalusi. Reaalsete asjade abil saab rääkida mitmeid lugusid, nii neist, kes selle valmistasid; neist, kes sellest unistasid, kui ka neist, kes sellega koos elasid ja olid. On ju näitus muuseumi põhiline ühenduse pidamise koht külastajaga. See on koht, kus esitada oma lugu, anda edasi elamusi või pakkuda iseproovimise võimalust (Kallio 2004: 82-83).

\section{Püsiekspositsioon, näitused ja üritused toiduteema teenistuses}

Kõige pikaajalisem Hiiumaa muuseumi püsiekspositsioon on olnud Kassaris endises mõisavalitseja ja antvärkide majas.

Tollases rajooni ainukeses ja üsna pisikeses muuseumimajas, mis asus pealegi keskustest kaugel, polnudki esialgu eraldi näituseruume peale püsiekspositsiooni oma. Nõnda ei saanud seal ajutisi näitusi korraldada ja kohalikule toidukultuurile viitas vaid improviseeritud talutoa nurk rehetoast pärit laua ja puunõudega. Mõne aja pärast tehti siiski otsus püsinäituse arvelt ajutisteks näitusteks pisutki ruumi teha. Üks esimesi eriväljapanekuid, mida võis juba näituseks nimetada, oli „Hiiu õlu" (1984). Sellist valikut toetas näituse koostaja kodust kaasa saadud teadmine ehk vaimne pärand ja huvi materjali vastu. Seda, et väikemuuseumide näitusepoliitikat mõjutas ja mõjutab küllap praegugi suuresti muuseumitöötaja(te) varasem erialavalik, on selles töös hästi märgata. Kohaliku hiiu õlle teema ei ole aga Hiiumaa muuseumi tegemistest kadunud, sest sellest on valminud üks sissekandeid UNESCO Eesti vaimse pärandi nimistusse, ${ }^{1}$ samuti on sellest kirjutatud tekste ja antud nõu ruumikujunduse kohta kohalikule ôllekojale Kassaris. See on olnud üheks ülesandeks gümnaasiumitaseme õpilasprojektis ja jõudnud sel moel ka kirjutisena Hiiumaa turismikataloogi (Käär 2010/2011: 32-33). Seega võime öelda, et 1984. aastal alguse saanud otsene või kaudne tegevus on midagi, mida saab hinnata partnerlusena kogukonnas. Teadmised selles vallas ei ole tulnud päris iseenesest, vaid ikka huvi tundes ja uurides. Samas arhiivisäilikuid sellest muuseumikogusse ei lisandunud. Tõsi, on olemas õllekoja trükitud voldik ja pedagoogilise materjalina saab kasutada Leemet Kääri esitlust ning kogusse kuulub ka kataloog tema artikliga.

Teeme ühe tagasivaate ka aastasse 1983, mil toimus muuseumi esimene suur aastavahetusenäitus ajale kohase nimetusega näärinäitus. See oli omamoodi kobav

[1] http://www.rahvakultuur.ee/vkpnimistu/index.php?page=Public.Knowledge\&area_ id $=0 \& i d=129$ 
katse võtta ette midagi uut või õigemini siduda teadaolevat vana uuega nii kombestiku, kodukujunduse kui käsitöönäidete kaudu. 1984., 1985. ja 1986. aasta näärinäitustega kaasnes jõulisemalt juba ka toiduteema. Trükkisime siis esimest korda väikesed voldikud pealkirjadega „Näärinäituse retseptid I ehk Keiksuggused kogid” 1984, „Näärinäituse retseptid II ehk Road rohhoaia rohtodest” 1985 ja „Näärinäituse retseptid III ehk Suppid ja Worstid” 1986. Trükistes tõime välja valiku õpetusi vanadest kokaraamatutest ja ajakirjadest ning pisut ka koduretsepte, innustuseks meie kogus olev 1824. aastal välja antud kokaraamat (HKM 2577:5 R 233).

Retseptilehtedele toeks tegutses mõnel õhtul väike teetuba ja kaasa sai osta pakikesi kohalike kuivatatud ürtidega ning maitsta mõnda neist vanaviisi tehtud kookidest. Retseptilehed ja üritused ise olid väga menukad. 1994. aastal alustasime uut aastalõpusündmuste sarja, millest kasvasid välja meie ülimalt populaarsed jõulumaad. Eriti rahvarohketeks osutusid teemanädalad pealkirjade all „Jõulud läbi kahe aastasaja”, "Sajanditagusest klassitoast mõisa jõulupuule”, „Vabrikutöölise jõulurõõm" jt. Olgu siin ära toodud üks katke näitust tutvustavast reklaamlehest: „Reigi 1863 - rehetuba ja ait. Pimedavõitu rehetoa seinad on linaste kangaste ja pillirooga kaunistatud. Kuuseoksad põrandal, krässid-kroonid laes lisavad jõulutunnet. Igaüks pere liikmetest loodab kõhu pühadevorsti (makki), sealiha ja puhast leiba täis vitsutada. Ükskord ometi ... ja ka esivanematele peab jätkuma. Jõulupuki tuleb nooremat rahvast lõbustama, vanemad sätivad end õllekannu ümber

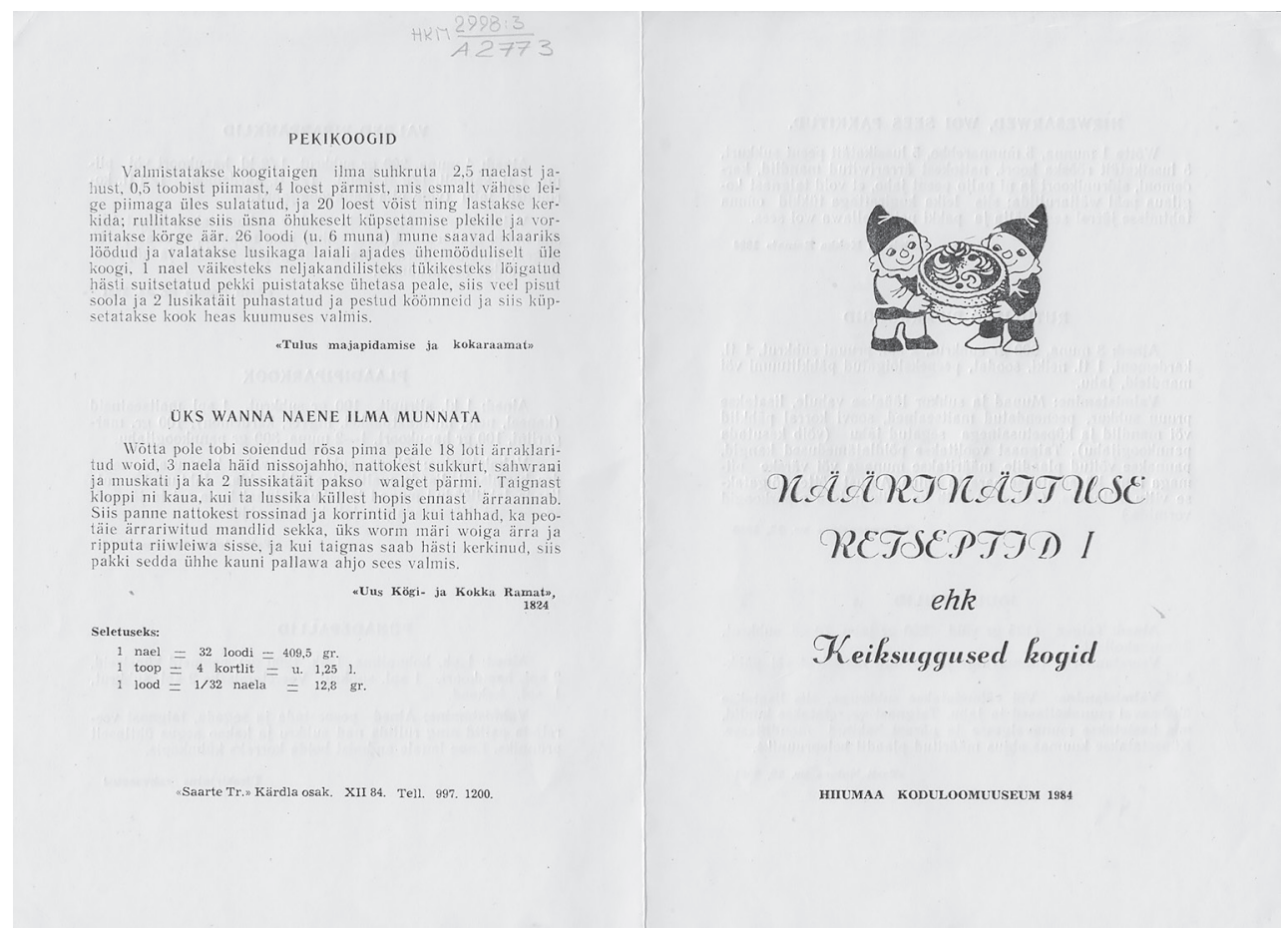

Foto 3. Näärinäituse voldik aastast 1984 


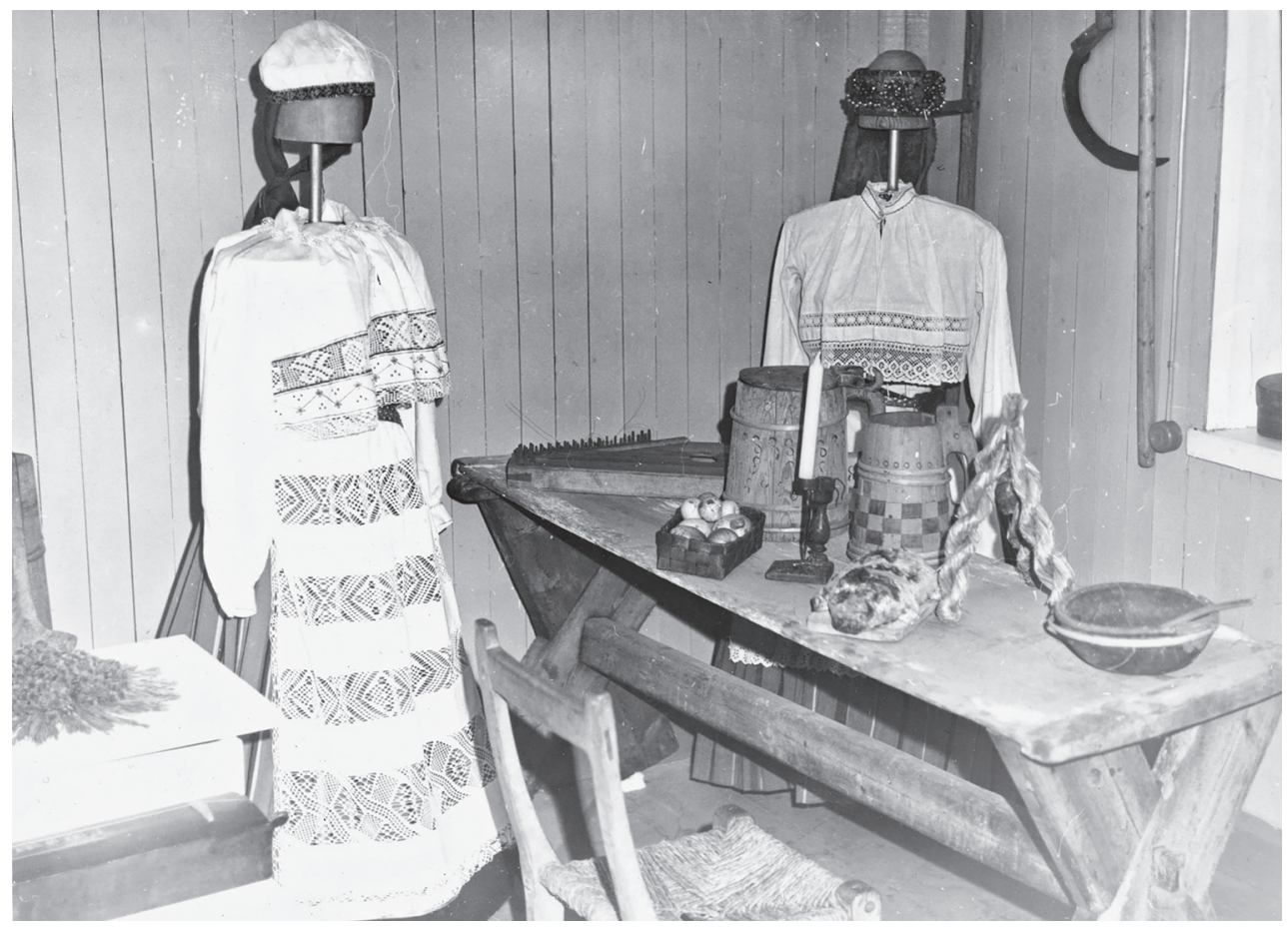

Foto 4. Püsiekspositsiooni kohandamine näärinäituseks. Laual jõuluorikas.

Foto: Guido Paomees 1985

maailmaasju rääkima ja uue aastaringi märke mõistatama. Ja valgemaks läheb ..." Lihtsalt kirjeldus, mis tuletab meelde vanu aegu. Aga selle juurde käisid lõhnad, hääled, maitsmine ...

Kõigil tollastel näitustel, osalusetendustel ja matkadel oli üht- või teistmoodi seos kohaliku või üldisema jõulu- ja nääritraditsiooniga, kus söögitegemisel, lauakatmisel, lihtsalt lõhnadel ja maitsetel on olnud kanda suur roll. Neid ajalooga vähem või rohkem seotud toidumaitsmisi kroonis alati mere ääres nääri- ja jõuluvana koja juures lõkketulel suures katlas keedetud vaarika- ja piparmündivartest või kevadel korjatud nurmenukkudest taimetee (Põllo 1996). Selleski oli oma annus pärimuse edasikandmist.

Aastaid hiljem jätkusid jõuluüritused muuseumile kuuluvas arhailises Mihkli talus, kus tegevused olid ehk rohkem metsa- ja matkakesksed, aga juba kuulsaks saanud ürditee ning mõned söögiampsud maitsestasid neidki külastusi. Sellised, enamasti näitusteks nimetatud ettevõtmised olid programmides mängulise iseloomuga, kuid need olid siiski ajaloole toetuva õpetliku sisuga ja toidul oli neis sageli pigem emotsionaalne kui informatiivne roll.

Üks olulisemaid näitusi Hiiumaa Muuseumis, mille aluseks oli põhiliselt söömise ja toidu teema, kandis pealkirja „Millest räägivad nõud?” (2000). Selle tutvustuses seisab: „Selles ekspositsioonis on nõud nii söömiskultuuri peegeldajana, tarbekunstina, valmistaja oskuste näitajana, koguja meelisobjektina, ajaloosündmustes 
osalejana, ajastu moe, materjali ja vormikasutuse tutvustajana, perekonna-aardena, aga ka prügina. Juba Piiblis on kirjas, et kõik inimese vaev on ta suu jaoks ja isugi ei saa otsa. Tõepoolest, toitumine on elu alus, sest just söömisega saadakse elutegevuseks vajalik energia ..."

Näitusel oli vaatajate ette seatud väga mitmeid teemasid, näiteks lauakatmise oskus, kokkuhoid ja kasinus 19. sajandi õpilastele koolisupi keetmisel või ühekordsete nõude kasutamise mõistlikkus või mittemõistlikkus. Esile olid toodud nii ühest kausist söömine talumajas kui mõisarahva uhke einestamine pika laua taga, samuti töötingimused nõukogudeaegse söökla tagaruumis. Ühe näitusetoa püüdsime sisustada samasuguste esemetega, mis olid kirjas Kõpu kooliõpetaja 1905. aastal koostatud varaloendis (HKM 4266:1/A1510). Kasutasime inspiratsiooniks peaaegu kõiki muuseumi arhiivis olevaid käsikirju. Mitmekesine näitus kahel korrusel, mille muutis veel värvikamaks kohaliku kollektsionääri Silvia Õunapi kannude ja mõisanõude kogu, võimaldas teha palju programme nii õpilastele kui ka täiskasvanutele. Näitus oli mõeldud ennekõike kohalikele inimestele, sest see oli avatud veebruarikuu viimastest päevadest aprilli keskpaigani. Seda külastas üle 500 inimese. Tagantjärele tarkusena saame öelda, et väljapanek oli eksponeeritud liialt lühikest aega. Samas tasub märkida, et muuseumi nõudekogu täienes selle järel märkimisväärselt, ehkki mõjusama pedagoogilise töö jaoks jäi aega napiks.

2000. aasta oktoobris toimus muuseumis ka leivanädal, kus osales üle 700 noore inimese (Sameli 2000). Osavõtjate arvu kasvatas tublisti üleriigiline kampaania ja

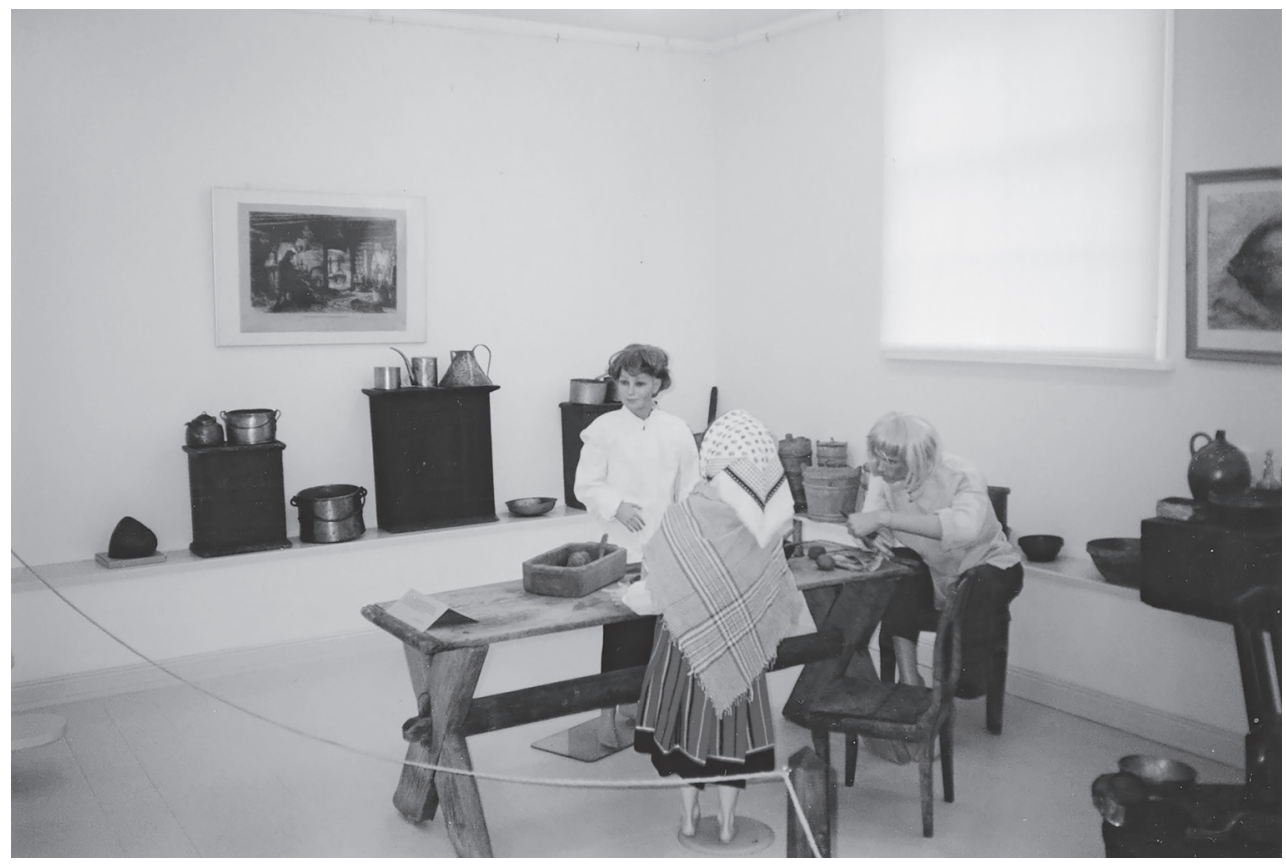

Foto 5. Vaade näitusele „Millest räägivad nõud?"

Foto: Urmas Liit 2000 


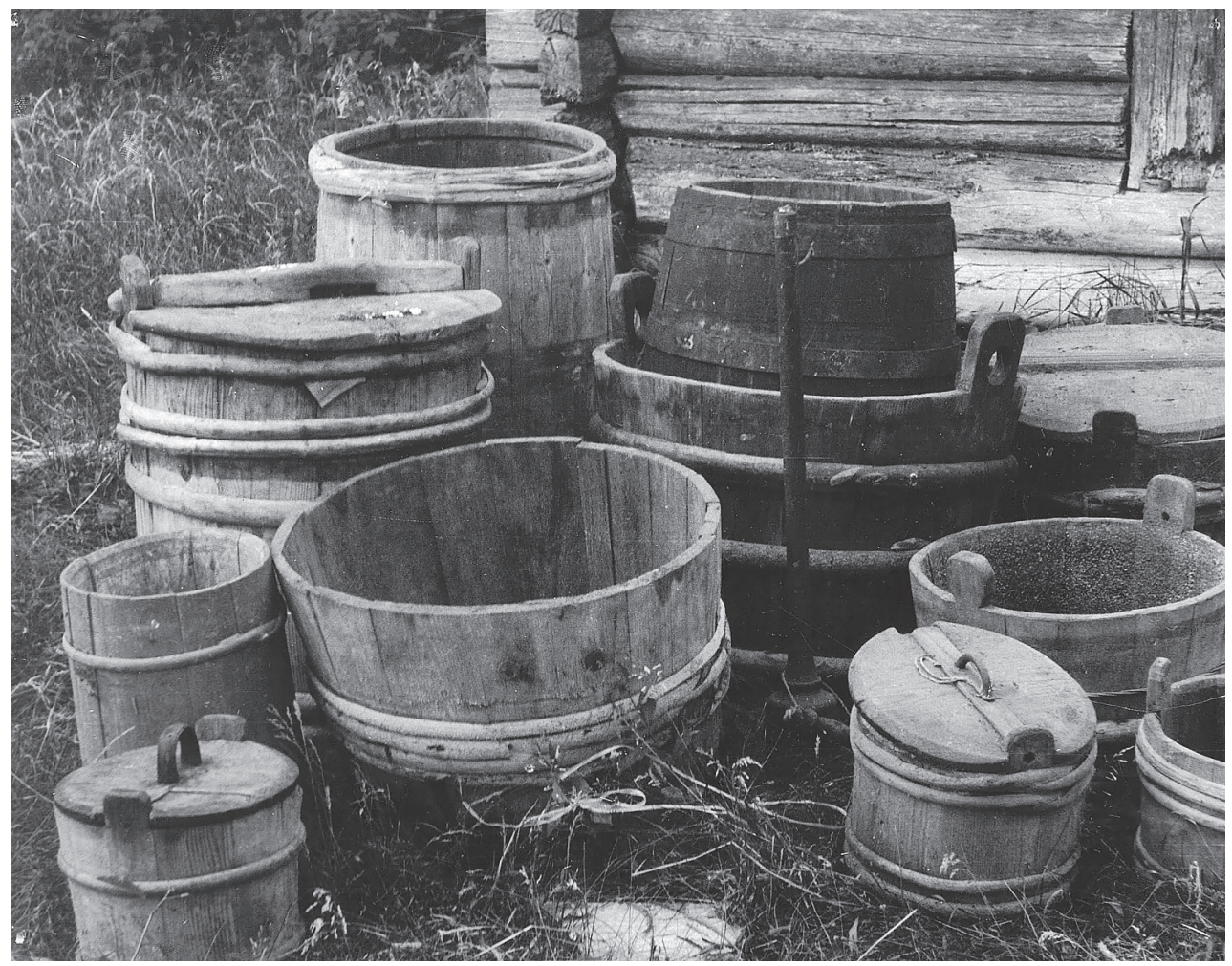

Foto 6. Vanad puunõud Malvaste küla Mihkli talu aida ees.

Foto: Kairi Sikkar 1988

kohaliku leivamaja valmisolek meiega samal ajal külastajaid vastu võtta ning muuseumitunde värske leivaga varustada. Koostööprojektid on ikka olnud rahvarohkemad ja edukamad kui need, mida üksi ette võetakse. Neis on olnud lihtsam luua ajaülest sidet ehk võrrelda minevikku tänapäevaga ja meelitada kohale mitmesuguse tausta ning huviga osalejaid.

Kui veel mõnele näitusele osutada, siis otseselt või kaudselt andis toidust ja elukorraldusest aimu 2006. aasta suur väljapanek pealkirjaga „Hüvastijätt pütiajaga”. Sissejuhatava teksti ja muude näidete kaudu said külastajad teada, et hiidlased valmistasid puunõusid sageli müügiks või selleks, et nende eest vahetuskaubana vilja saada. Just selline vahetuskaup aitas paljudel saareelanikel eluga toime tulla, kuna kehv põllupinnas ei andnud eriti saaki. Näitus tutvustas eri tüüpi laudnõusid, nende nimetusi, otstarvet ja valmistamise ning kasutamise omapära. Sarnasel moel, kuid teisest materjalist esemete kaudu tegi joogikultuurist juttu näitus „Hüti klaasikoda 375”. Ja mitte ainult juttu - selle näituse ettevalmistamisel õnnestus meil teha koostööd klaasikunstnik Maie-Ann Raunaga, kes osales koos Maks Roosmaga aastate eest Hiiumaal Eesti esimese klaasikoja asukohas ka väljakaevamistel. Meie koostöö kujunes nii inspireerivaks ja tulusaks, et saime näitusel kasutada ja veel mitu aastat muuseumipoes müüa kunagise ettevõtte Tarbeklaas järglaste taasloodud, kuid Hüti 17. sajandi toodanguga sarnaseid joogiklaase, peekreid jm. Ka 
2001. aasta näitus „Ühistu auks” käsitles piima- ja munaühistute tegevuse ning ühiskaubanduse algusaegade loo kaudu toiduteemat sootuks teisest vaatenurgast. Seda ilmestas rohkete sõjaeelsete kaubapakenditega poeruum ja piimanõudega meiereiesine.

Väljapanek „Hiiu pulm. Tagasivaade” 2011. aastal puudutas põgusalt 19. sajandi pulmatoitude valmistamist, pulmarahva lauas istumist ja söömist, kuid jäi tõesti vaid tolleaegse toidukultuuri puudutuseks. Selliseid lühi- ja lähivaateid hiidlaste toidulauale pakkusid mõned muudki väljapanekud. Olgu siinkohal mainitud meie enda näitust kalatöötlemisest või hoopis lugusid kartulist, kandvaks osaks Eesti Rahva Muuseumi kogud. ERMi ja Hiiumaa gümnaasiumiõpilaste ühisnäitus välismaal elavatest kaasmaalastest (,1/10 eestlust“, 2014) tõi selgelt välja, kui suur roll on toidul, näiteks mustal leival, soolakalal, kohupiimal jms kodu ja oma rahvuse meeles hoidmisel. Nii mõnelgi näitusel on inimestel olnud võimalus oma arvamust avaldada, lemmiktoite nimetada, kuid selline anonüümne vastamine ei ole kahjuks rikastanud muuseumi arhiivi uute säilikutega.

Muuseumi viimase aja üks suuremaid toidu- ja söögiteemalisi näitusi kandis pealkirja „Køøk“ (kirjapilt tuleneb sellest, et näituse koostajad tahtsid viidata hiiu keele hääldusele, kus kahte kõrvuti öö-d hääldatakse õ ja ö vahepealselt). Seda ekspositsiooni oleks võinud iseloomustavalt nimetada ka "Saja aasta neli kööki”, sest just selline valik kajastus ülesehitatud interjöörides. Olid 1930. aastate talumajast, 1950.-60. aastate Kärdla majast, ühest 1970.-80. aastate korterist ja 1990. aastate üleminekuperioodi kodust pärit köögid. Külastajad hindasid seda näitust ennekõike äratundmisrõõmu pärast ja võimaluse eest tunda end osalisena ajastupärases keskkonnas. Näituse laiem mõte oli tekitada arutelusid inimeste valikuvõimalustest elukoha leidmisel ja köögist kui kodu südamest ning paljude otsuste vastuvõtmise paigast. Selle pikemaajalise väljapanekuga kaasnes mitmeid toiduteemalisi toimetamisi lastega (näiteks jõuluprogramm lauakatmise ja piparkookide valmistamisega, lõhnade tundmise töötuba ning programm „Korstnad puhtaks ja kööki!“).

Köögiteema on kokkusurutumalt ja väiksema tähelepanuga esile toodud ka 2017. aasta näitusel „Täna 50 aastat tagasi”, mille ühe osa moodustab 1960. aastate elamise näide Hiiumaalt. Samas on eri aegade köögid olnud pidevalt esindatud meie filiaalides, näiteks R. Tobiase majas, Mihkli talus Malvastes, Kroogi talus Valgul ja Kärdla püsiekspositsioonis vabrikutöölise maja näitel. Viimasest on ühtlasi kujunenud muuseumi kõige muutuvam ja elavam püsinäituse osa.

Üks väike toidualane täiendus puudutab veel näituste avamist, kus külalistele mõeldud suupistelaud on ikka ja jälle saanud innustust väljapaneku sisust või ajastu maitsetest. Meenuvad ammused koolilaste pekileivad ja kuum tee, ekspeditsioonile omased kalakonservid ja termosekohvi või kiluampsud kartuliga, rääkimata tangupudrust, kartulisalatist, supist ja kodukoogist. 


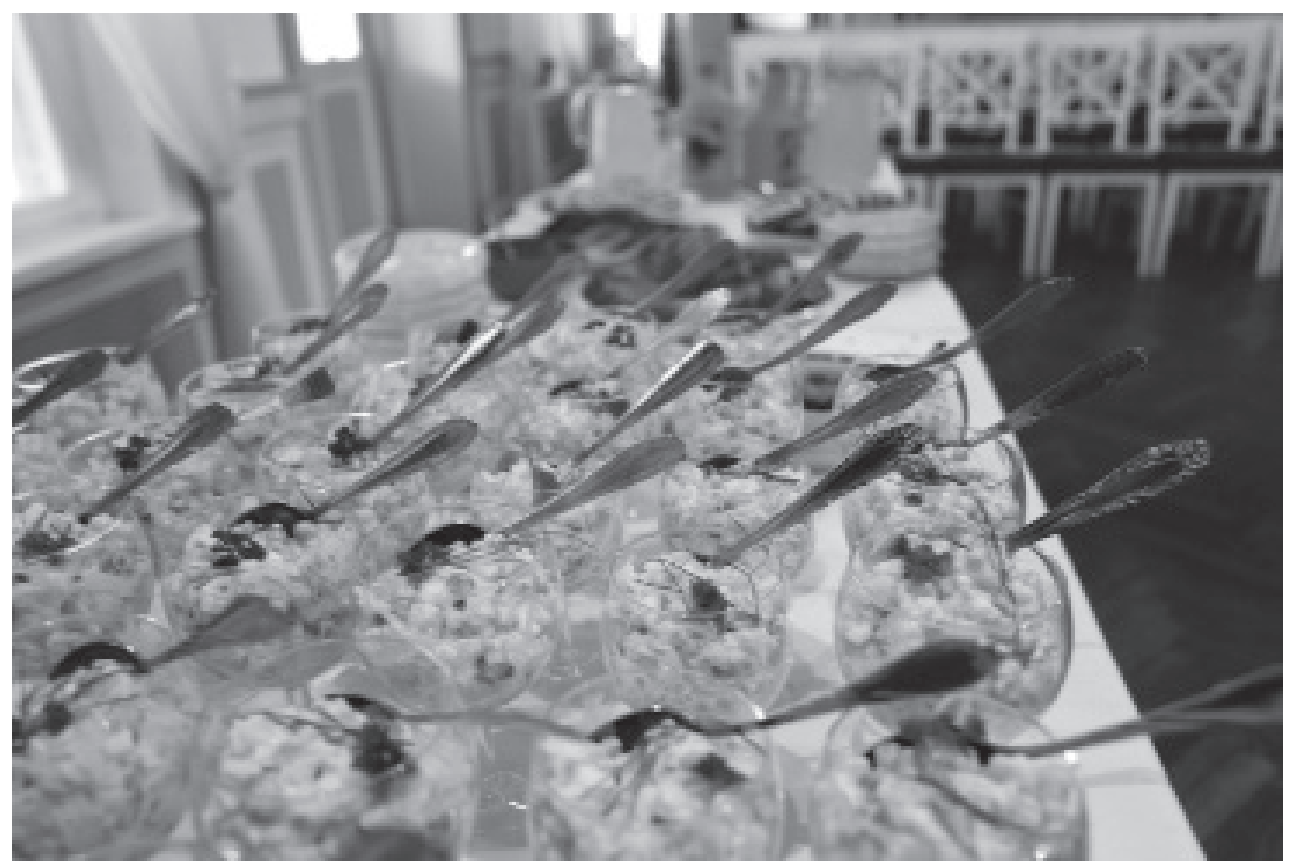

Foto 7. Kartulisalat „Köögi“ näituse avamisel.

Foto Urmas Liit 2015

\section{Toidu osa muuseumi ühepäevasündmustes}

Muuseumi sündmuste jada on olnud kirev ja mitmetahuline. Toon siin esile mõned värvikamad.

Aastail 1994-2000 tõstis väikesel Kassari saarel asuvat muuseumi pildile igaaastane hilissuvine õueüritus „Parunipäev“ (Roosna 2000). Koos esemenäituste, tööde-tegemiste tutvustamiste (võrgu- ja korvipunumine jms), tantsuetenduste, lavajantide ja pannkoogiküpsetamiste oli päeva naelaks tasuta tort. Selle valmistasid Hiiumaa pagarid-kondiitrid, aga kaunistuse juures saime ka ise kaasa rääkida. Tordi pakkumise idee oli laenatud kunagiste parunite heategevusüritustest ja toimis hästi ka uutes oludes. Mõneti toetas meie muuseum selle iga-aastase sündmusega ja temaatilise tordi tellimisega ehk ka kohalike pagarite oskuste edenemist. Purgid pannkoogisõbraliku moosiga täitusid aga muuseumitöötajate endi kodus samuti igal parunipäeva aastal. Seega oli taas tegu katsetega jõuda elamuse (isegi maitseelamuse) kaudu külastajani. Nagu teada, võib just elamus väga hästi n-ö müüa" (Raisma 2009: 36-37) ka tasuta üritusel. Ennekõike said inimesed sel päeval toredalt aega veeta ja nalja, naeru, uurimise, iseproovimise ja kogemise kaudu uusi teadmisi hankida. Pole ehk liiast märkida, et kui muuseumi enda sündmused kõrvale jätta, on üks kogutud ese veel ühele suurele ja tähtsale torditegemisele sisu andnud. Nimelt kujutas 2003. aasta maavanema vastuvõtutort ehedalt ja ehtsalt hiidlaste puust lüpsikut aastaarvuga 1510. Isegi nii ehedalt, et paljud arvasid selle ehtsa muuseumi lüpsiku olevat. See fakt tuletab meelde, et ka sellistes argielulistes tegevustes nagu 


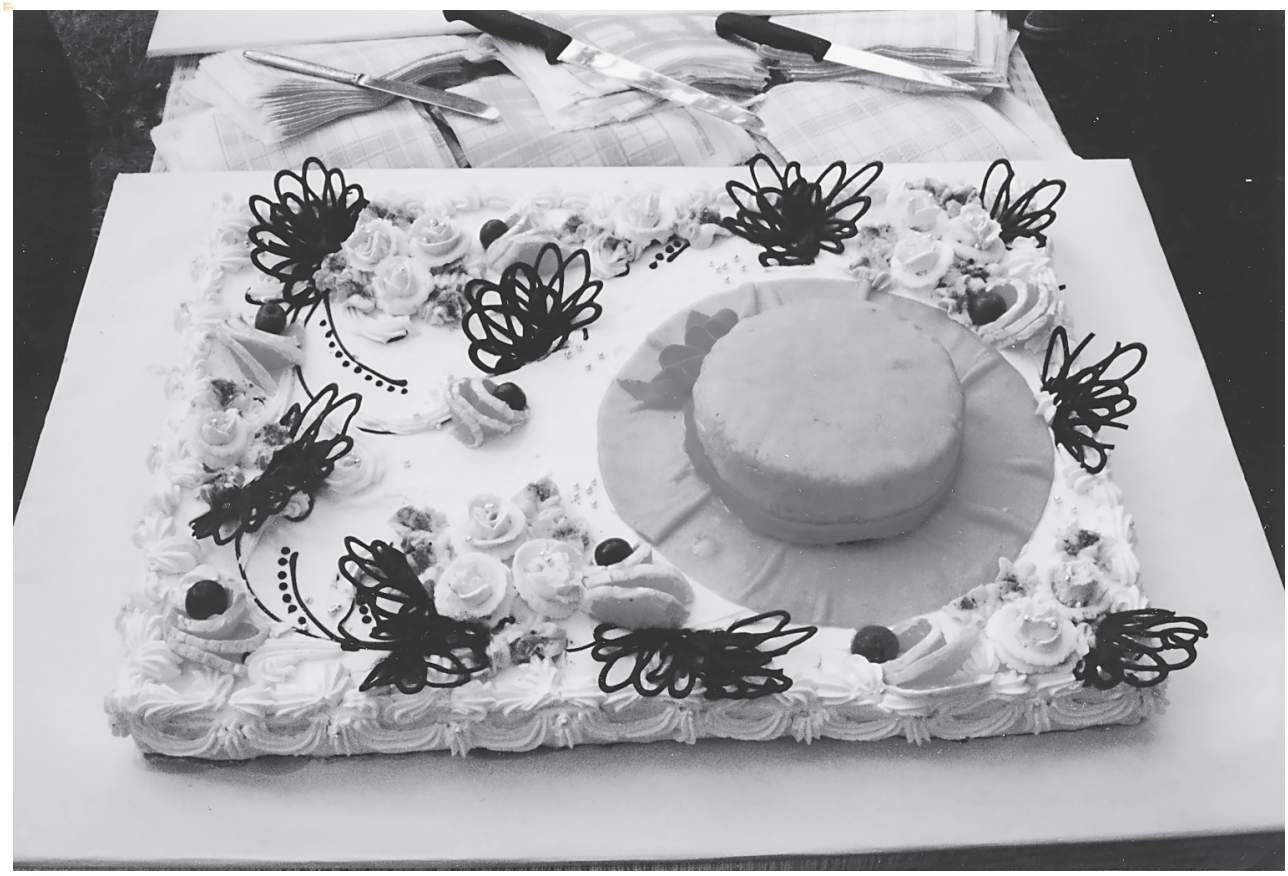

Foto 8. Parunipäeva tort.

Foto: Urmas Liit 1998

toiduvalmistamine ja söömine on oma kõrghetked, mida muuseum võib ja lausa peab selgemalt jäädvustama.

Mihkli talu suvesündmustest tasub meelde tuletada lehmapidajate päeva 2004 . aastal. See oli mõeldud Kõrgessaare valla väikelehmapidajatele, keda oli tollases 1500 elanikuga vallas 50 ringis. Märkimisväärne osa neist tuli kutse peale ka kohale. See värske piima maiguga päev jäi kõigile meenutama lihtsat puhast ja värsket maatoitu. Igaüks võttis kodust midagi kaasa, oli see siis isetehtud jogurt, hapupiim või sõir (mida meil kutsutakse enamasti juustuks). Võid vändati kokku vanas kirnus kohapeal. Kümme aastat hiljem, aastal 2014 oli sellele päevale samast piirkonnast kutsuda veel ainult kolm väikelehmapidajat ning varasemat ühe kandi loomapidajate arvu ei saanud kokku isegi kogu Hiiu saarelt. Enam ei tundunud kutsuvana ka värsked kodused piimasaadused, mida suviselt õues pakuti. Sellised asjad annavad väga selgelt märku aja, olude, aga ka inimeste muutumisest. Loomulikult andis ja annab Mihkli talu edaspidigi hea võimaluse näha ja kuulda, millise arengu on läbi teinud talurahva söögitegemise tavad ehk milline on olnud toidu teekond reheahjust pliidini või karjamaalt-põllult keldrisse ja potti. Muuseumi omaaegsed katsed turismigruppe tangupudru või muu toiduga teemale lähemale viia lõppesid ühel hetkel karmimate õues toitlustamise nõuete tõttu. Muuseum ei jõudnud neid enam järgida ja see konkreetne unistus mäluasutuse elavdamiseks jäi seetõttu täitmata. Aga nagu teada, tekib võimalusi ikka juurde. 


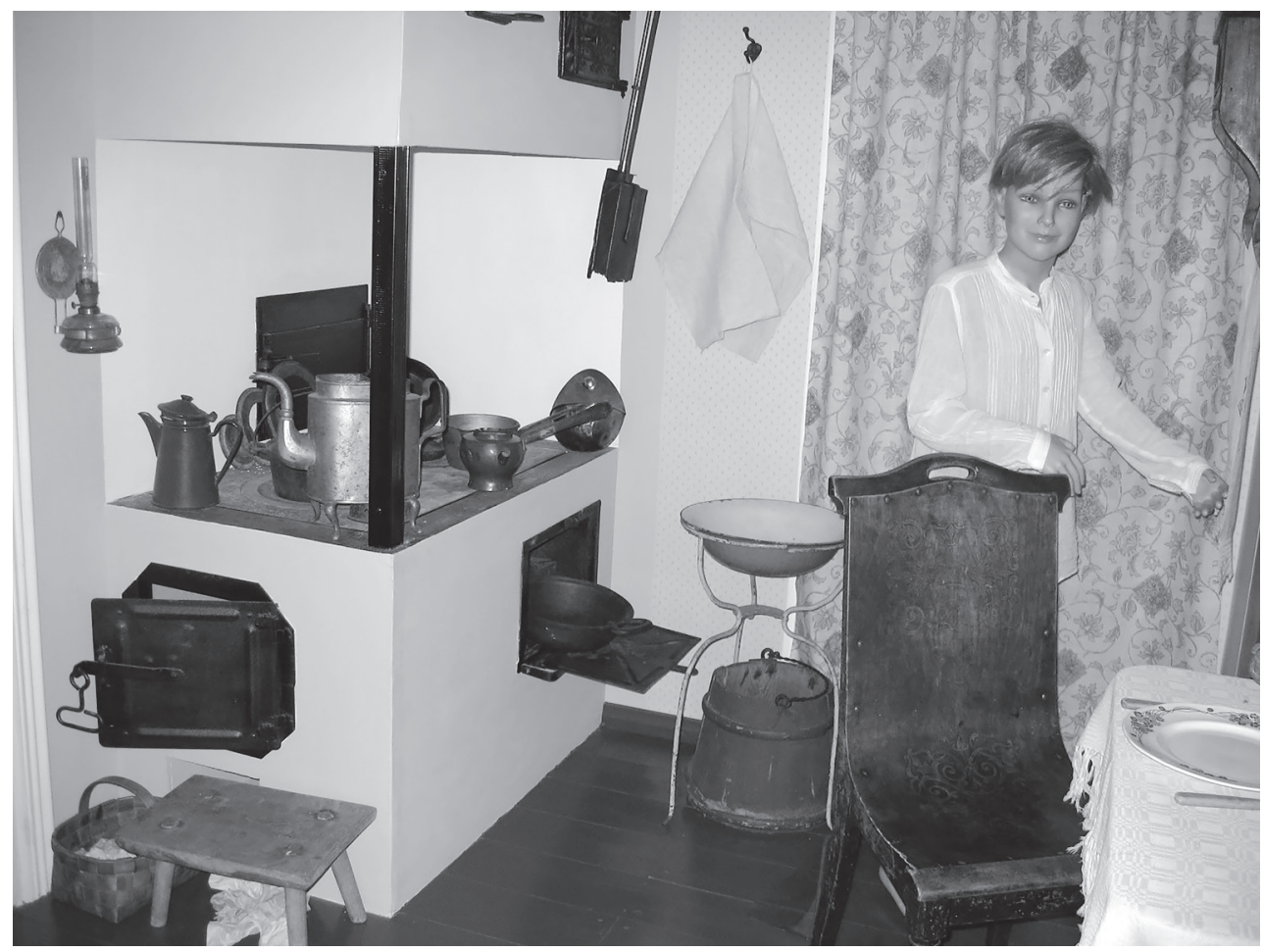

Foto 9. Kärdla püsiekspositsiooni vabrikuaegse maja köök mannekeeniga. Foto: Urmas Liit 2004

Kärdlas nn Pikas Majas, millest oli aastal 1998 saanud muuseumi peamaja, tekkis hoopis uus võimalus näituste ja ürituste korraldamiseks. Üheks neist kujunes salongiõhtute sari. Esialgu üsna lihtsa plaaniga kavandatud kohviõhtud muusika, luule või kunsti seltsis (aastatel 2002, 2003) kujunesid mõne aja järel võrdlemisi pika ettevalmistusaja ja täpse teemavalikuga kultuurhariduslikeks koosviibimisteks. Üks huvitavamaid ja mitmekesisemaid oli kindlasti 23. aprillil 2004 toimunud taaslavastus Hiiu-Kärdla kalevivabriku raamatupidaja 15 aasta tööjuubelist 1938 . aastal. Kui söömisest rääkida, siis valmistasime seda õhtut ette kui koolituskeskuse Tuuru turismi- ja teeninduskursusepraktika ülesannet. Praktikandid osalesid kogu sündmuse kavandamises ja läbiviimises, õppisid toitu kalkuleerima ja valmistama, samuti lauda katma, kaunistama ja serveerima. Lisaks tuli veel otsida ajastupärane riietus ja nõud. Leheartikkel meenutab: „Nii, nagu kombeks pidusid tähistada, olid Kärdla kodukaunistamise seltsi prouad kenasti lauale seadnud sülti, heeringasalatit, seeni kuumade kartulitega ..." (Roosna 2004). Ettevõtmine osutus menukaks. Ja kui 2007. aastast hakati Kärdlas tänaseks juba tuntuks saanud kohvikutepäeva pidama, oli muuseumil taas oluline roll mõtte kergitamisel ja idee teostamisel, kuid ennekõike muidugi ajaloolise tausta mõtestamisel. Seega tuli uurida ja selgeks teha ajaloolised tugisambad, millele see toetuda võiks. Kohvikutepäeva 


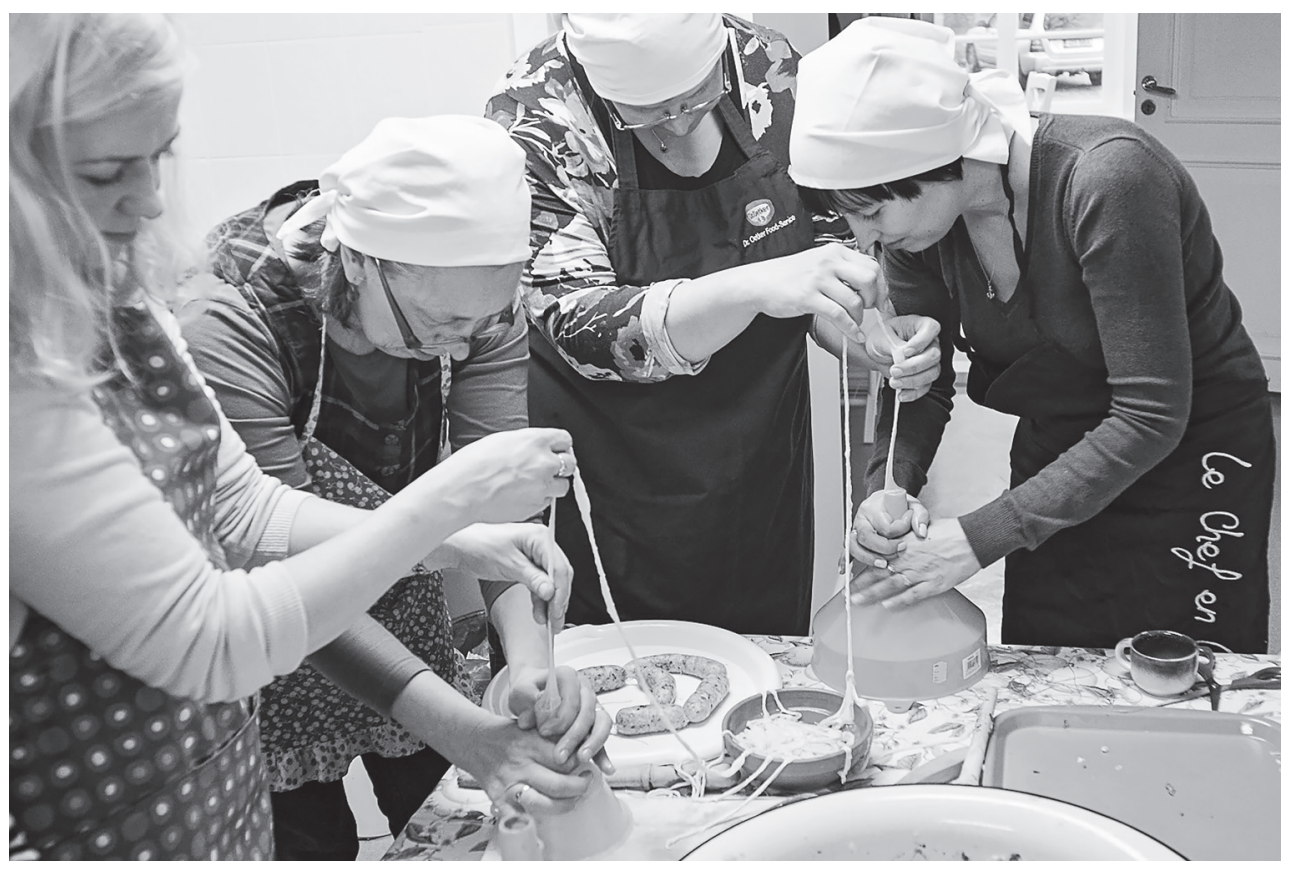

Foto 10. Jõuluvorstide valmistamise töötuba muuseumi õppeklassis. Foto: Toomas Kokovkin 2015

iga-aastase ettevalmistusprogrammi hulka kuuluvad ka koolituspäevad, kus muuseumil on andmepanga ja töötajate teadmistega täita oma kindel osa. Muuseumi ühepäevakohvik „Parunite Balkon” on samuti otsinud üha uusi võimalusi, et väärtustada ja tutvustada kohalikku toidukultuuri ajalugu. Samas ei anna üheks päevaks püsti pandud kohvikohad eriti häid võimalusi suurema toidu tegemiseks, pigem tuleb piirduda ikka lihtsate küpsetiste ja pirukatega, mille ajalugu polegi meil märkimisväärselt pikk. Ometi on kohvikutepäeva üks suuremaid tähendusi selles, et väga paljud hiidlased koos sõpradega võtavad sellest elamuspäevast osa, loovad oma lugu ja saavad teada kodukoha ajaloost.

\section{Töötoad ja kogemusõpe}

Korralikuks toiduvalmistamise töötoaks või õppepäevade tarvis peavad olema head tingimused, mida on väikemuuseumides keeruline luua. Samas saab nii mõndagi ära teha. Päris väikeste lastega oleme toidust rääkides voolinud näiteks plastiliinist kruuse-kausse või seakujulist jõululeiba. Killukesi oma vanavanemate toidutavadest panid kirja ka Kärdla kooli neljanda klassi õpilased, kellega sai terve kooliaasta jooksul (2003) proovitud ajarännaku ideed, mille üheks oluliseks osaks oli esivanemate mälestustel põhineva uurimistöö koostamine. Nende lastega toimetasime terve päeva ka tüüpilises 1930. aastate talus ning tegime pärast väsitavat 
tööd n-ö vanal moel puupliidi peal üheskoos süüa, katsime laua ja võtsime einet. Üks eriti edukas toidutöötuba, mis toimus 2015. aastal muuseumi uuendatud õppeköögis, oli seotud veri- ja tanguvorsti valmistamisega. 12 kohta said hetkega täis ja isetehtud jõuluvorstid maitsesid tegijatele hästi.

Mitu aastat kestnud projekt üldise pealkirjaga „Pärimuse kaudu hiidlaseks" hõlmas gümnaasiumiõpilaste mõeldud koduseid ülesandeid, mis eeldasid toidutegemise tavade uurimist ja jäädvustamist (süldi tegemine, koogi küpsetamine, munade värvimine jne). Selle projektiga sai pärimuslik teema ühendatud inglise keele ja arvutitundidega ja tulemuseks oli ingliskeelne powerpoint-esitlus.

Muuseumi kogemusõppes osalejateks võib pidada ka neid vabatahtlikke, kes on aastaid osa võtnud meie kohvikutepäeva köögipoolest või askeldanud jõulumaal ja parunipäeval. Tagasiside on olnud üldjuhul väga positiivne ning mitmed noored on selle kogemuse ka oma CV-sse kirja pannud.

\section{Kokkuvõtteks}

Loomulikult puudutab söömine ja toiduga tegelemine meid kõiki. Seda enam on huvitav jälgida, kui palju jääb sellest jälgi sellisesse mäluasutusse nagu regioonipõhine muuseum; kui tähtsaks me seda kõike praegu peame ja mida suudame teha tuleviku jaoks. Suhteliselt väiksearvulisele kohalikule kogukonnale (u 9000 püsielanikku) toetuv Hiiumaa Muuseum (nüüd SA Hiiumaa Muuseumid) on paindliku töökorraldusega asutus, mis on püüdnud jälgida ja järgida oma sihtgruppide huve ning vajadusi nii näituste ja ürituste korraldamisel kui ka kogude täiendamisel. See, mis muuseumis toimub, jõuab kogukonna liikmeteni mitmel moel, kuid igal juhul kiiresti. Nii saame kiiresti ka tagasisidet ja arvamusi, kuidas oma tegevust paremini korraldada. Muuseumil on suur hulk toetajaid, kes on aidanud teha selliseid näitusi nagu „Millest räägivad nõud?” (2000) või „Köök” (2015-2016). Võrdlemisi suur osa nähtud esemetest oli kogukonnaliikmetelt laenatud. Kui palju materjali peaks kogudes säilitama ja kui palju lihtsalt kirjeldatuna arvele võtma, jääb igikestvaks küsimuseks. Praegu arutleb selle üle muuseumis väikesearvuline vastuvõtukomisjon. Pole kahtlustki, et väikemuuseumis on komisjoni ühel liikmel neis otsustes ja ka kogumispõhimõtete väljatöötamisel suur kaal.

Suurtel aastavahetusnäitustel, parunipäevadel, salongiõhtutel ja kohvikutepäevadel on abiks olnud kümned või isegi sajad vabatahtlikud. Kindlasti vajavad veel paljud olulised teemad põhjalikku analüüsi, et mõtestada senisest paremini nii kogumispoliitikat kui ka missiooni ja muuseumi rolli ühiskonnas laiemalt. Toidu ja söömise teema ülesvõtmine andis selle üle arutlemiseks taas tõuke. 


\section{Allikad}

Hiiumaa Muuseumi aastaaruanded. 1968-2016. Hiiumaa Muuseumi arhiiv

Hiiumaa Muuseumi näituste materjalid. Hiiumaa Muuseumi käsiraamatukogu

SA Hiiumaa Muuseumid museaalide kogu (HKM)

UNESCO vaimse pärandi Eesti nimekiri

Põllo, Helgi 2007. Muuseum täiskasvanute õpikohana ja kohaliku identiteedi hoidjana. Hiiumaa muuseumi näide. Käsikiri autori valduses.

\section{Kirjandus}

Kallio, Kalle (toim.). 2004. Museo oppimisympäristönä. Suomen museoliiton julkaisuja 54. Jyväskylä: Gummerus.

Kannike, Anu. 1999. Elustiili dokumenteerimine. Kodu kui sümboolne keskkond. - Eesti Rahva Muuseumi Aastaraamat XLIII. Tartu: Eesti Rahva Muuseum, 55-61.

Käär, Leemet. 2010/2011. Kuidas hiidlane õlut teeb. - Hiiumaa turismikataloog, 32-33.

Kokovkin, Toomas. 2015. Riigimuuseumist sihtasutuseks. Poole aasta mõtted. - Muuseum 1 (37): 20-22.

Mairesse, Francois. 2010. Collection strategies now! - Pettersson, Susanna; HagedornSaupe, Monika; Jyrkkiö, Teijamari; Weij, Astrid (eds.). Encouraging Collections Mobility. A Way Forward for Museums in Europe. Helsingi: Finnish National Gallery, 54-71.

Liivamägi, Tiiu. 2004. Väärikaim muuseumieksponaat on krahvi teekann. - Hiiumaa 29.

Mensch, Peter van; Leontine Meijer-van Mensch. 2015. New Trends in Museology II. Slovenia Celje: Muzej novejše zgodovine.

Põllo, Helgi. 1996. Muuseumi jõuluüritus lõpusirgel. - Hiiumaa 148.

Pärdi, Heiki. 1999. Muuseum ja tänapäev. Kaasaja dokumenteerimise probleeme kultuuriloomuuseumides. - Eesti Rahva Muuseumi aastaraamat XLIII. Tartu: Eesti Rahva Muuseum, 72-86.

Raisma, Mariann. 2009. Muuseumiüritus kui muuseumi parim müügistrateegia. - Muuseum 1 (25): 38 .

Roosna, Harda. 2000. Parunipäev seitsmendat ja viimast korda. - Hiiu Leht 9 (93).

Roosna, Harda. 2004. Salongiõhtu. Vabriku arveametniku Hr. Heitmanni 15 tööjuubel Pikas Majas. - Hiiu Leht 34.

Sameli, Tiit. 2000. Leivanädalast saavad osa paljud. - Hiiu Leht 80.

Tamm, Marek. 2012. Kuidas kaitsta Eesti rahva mälu. - Loomingu Raamatukogu 28-30: 82-88.

Õunapuu, Piret. 2009. Muuseum müüb oma kogusid. - Muuseum 1 (25): 26.

Helgi Põllo lõpetas 1979. aastal Tartu Ülikooli ajaloolase-etnograafina. Ta on töötanud mitmel ametikohal Hiiumaa Muuseumis ja on praegu SA Hiiumaa Muuseumid teadusdirektor. Tema uurimisteemad on puudutanud Hiiumaa kultuurilugu, sh rahvariideid ja käsitööd, toitu ja söömist, laiaistmelisi kiiktoole, hiidlaste seltsideks jagunemist jms. Põllo oli Hiiumaa koguteose (2015) üks koostajaist, autoreist ning peatoimetaja. Ta on lisanud Hiiumaaga seotud sissekandeid vaimse pärandi nimistusse ning on UNESCO Eesti vaimse pärandi nõukogu liige. 


\section{Summary: Alimentary culture at Hiiumaa Museum. Collection, research, exhibition and outreach}

\section{Helgi Põllo}

We have reached an age when museums' collections, having rapidly increased in size, require substantive discussion on the need to continue acquisitions. Increasingly often we also encounter the question of whether cultural history museums that chronicle everyday life should devote more attention to aspects that affect practically all people, such as the topic of food and eating. We would do well to consider Maslow's hierarchy of needs. To this point, museums' focus has been more on art, achievements or decidedly material aspects. The article provides a concise overview of what the Hiiumaa Museum has been up to in the context of food and eating over its 50-year history. In the years following the establishment of the museum, attention in both exhibitions and collections was focused mainly on the tableware and utensils used for consumption or preservation of food, most of which originated in the 19th century. As time went on, activities were characterized by an increasing element of play enriched with knowledge (Soviet-era New Year's exhibitions, "baron's days", Christmaslands and other visitor-oriented programmes). The exhibitions themselves grew and changed, even if their titles remained simple: Millest räägivad nõud? (What does tableware have to say? 2000) or Köök (Kitchen, 2015). Over the years, the museum became a place to spend free time in, but also turned into a centre of expertise for the small local community on the matter of regional food traditions. This need for better knowledge on the subject also spurred the development of the museum's own research, surveys, and documentary efforts. As one example, we can cite the recorded responses to the question "What foods were on your Christmas table?", around the time of the first free Christmas celebrations in 1990. A problem related to the food topic, revealed during the preparation of the Hiiumaa compilation in 2015, was the paucity (or at least the one-dimensional nature) of images in the museum's collections.

As the museum grew and life changed, new programmatic events such as salon evenings and café days were devised. All these major undertakings required volunteer assistance, because the museum's own small team was not capable of covering the staffing needs of all these events. Outreach with students took place in all age groups - from nursery school to secondary school. Some of the assignments in the popular cooperation project involving upper secondary schoolers, "Becoming a Hiiumaa islander through tradition", also tied in with food. The more stringent food safety codes of more recent years have reduced the museum's possibilities for actually handing food or serving it to visitors. Still, a thing or two has changed over time, and in 2015, we organized a black pudding and white pudding preparation workshop in the museum's classroom. As interest in the food topic has risen among the locals and Estonia-wide, new topics keep on accruing in the museum's research sphere: e.g., drying of sheepshanks, making of head cheese. The best and most cha- 
racteristic examples make their way, with the museum's help, on to the UNESCO list of intangible heritage, but above all, they end up in the local museum's collections. Certainly many important topics require much analysis within the museum to make better sense of acquisition policies as well as the museum's mission and role in society as a whole. Once again, taking up the topic of food and eating has given impetus for this process.

\section{Резюме: Культура питания в Хийумааском музее: собирание, исследование, посредничество}

\section{Хельги Пылло}

Мы достигди такого периода времени, когда быстро разросшиеся фонды музея требуют содержательного обсуждения необходимости продолжать дальше пополнение коллекций. В то же время все чаще встает вопрос о том, следует ли отражающим повседневную жизнь культурно-историческим музеям обращать больше внимания в своей деятельности на то, что затрагивает практически всех людей, например, на тему еды и питания. 3десь уместным будет подумать хотя бы о пирамиде Маслоу. До настоящего времени в фокусе музеев находились скорее творчество, достижения или что-дибо очень материальное. Статья предоставдяет краткий обзор деятельности Хийумааского музея (сейчас ЦУ Хийумааские музеи). на протяжении 50 лет в связи с едой и питанием. В последовавшие после создания музея годы внимание как в экспозиции, так и коллекциях было сосредоточено в основном на посуде и принадлежностях, предназначенных для еды или хранения пищи, которые большей частью относились к XIX веку. Чем дальше, тем больше в мероприятия добавлялось обогащенной знаниями зрелищности (новогодние выставки, дни барона, рождественская страна и другие, предназначенные для посетителей программы). Росли и менялись сами выставки сохраняя прежние простые названия: «О чем говорит посуда?» (2000) или «Кухня» (2015). С годами музей превратился в место проведения свободного времени, но помимо этого музей для маленькой местной общины стал экспертом по вопросам региональных традиций питания. В то же время из этой необходимости - лучше владеть темой - выросли большие и малые исследовательские работы, опросники, пополнение фондов. В качестве одного из примеров можно привести записанные сразу же после первых свободных рождественских праздников в 1990 году ответы на вопрос: Какие блюда стояли на вашем рождественском столе? Тем не менее при составлении вышедшего в 2015 году сборника Хийумаа выяснилось то обстоятельство, что по-прежнему проблемой является малочисленность или однотипность фотографий на тему еды в фондах музея.

С ростом музея и происходящими в жизни переменами изобретадись новые программные события, такие как салонные вечера и раздичная деятельность в «Дни кафе». Для всех этих больших мероприятий требовалась помощь 
добровольцев, так как маленький коллектив самого музея не был бы в состоянии обеспечить потребность в рабочей силе на всех этих мероприятиях. Занятия с учениками проводидись также во всех возрастных группах - от детского сада до гимназии. Через несколько заданий с едой был связан и популярный совместный с учащимися гимназии проект «Жителем Хийумаа - через традиции». Связанные с гигиеной питания ужесточившиеся требования уменьшиди возможности музея реадьно заниматься едой или самим предлагать ее гостям. Но все же со временем кое-что изменилось и в 2015 году мы уже смогди организовать в своем учебном классе мастерскую по изготовлению кровяных и крупяных колбас. Поскольку интерес как местной общины так и вообще во всей Эстонии к теме питания постоянно растет, то в сферу исследований музея добавляются все новые, требующие рассмотрения темы: вяленье бараньей голени и окорока, приготовление холодца и пр. Самые лучшие и характерные образцы находят с помощью музея путь в список духовного наследия Эстонии в ЮНЕСКО, но прежде всего в фонды самого музея. Безусловно многие важные темы требуют основательного анализа внутри музея, чтобы дучше прежнего осознавать, как собственную политику пополнения коллекций, так и более широко миссию и роль музея в обществе. Постановка темы еды и питания в очередной раз дала к этому толчок. 